\title{
THE LIMITS OF DWELLING AND THE UNWITNESSED DEATH
}

\section{JASON DANELY Oxford Brookes University}

(iD) https:/ / orcid.org/0000-0001-8027-9328

The night I began writing this article started off like most others during my fieldwork. My two children had just gone to sleep, both of them curled up on a shared futon upstairs. Slowly, so as not to wake them, I stepped down the steep, creaky wooden staircase, hoping to squeeze out another hour of writing before I would slip into my own futon. Before I reached the ground floor, I began to hear ambulance sirens nearby. The old house I was renting was close to the Kyoto University Hospital, so hearing sirens was not too unusual, but this time they were louder and getting closer. Within seconds, the sirens were joined by the deep rumbling of an engine and bright red-orange lights that pulsed across the walls of my front room, sweeping through the windows. Breathless, I tumbled outside onto the narrow street just in time to see a crew of paramedics carrying a stretcher disappear down an alley on the opposite side of the street. The ambulance had stopped just a few steps away from my front door.

The ambulance lights flashed across the houses along the tightly packed street, most of which had already shuttered their windows for the night. Like most neighborhoods located within a few kilometers of the old Imperial Palace grounds in the historic center of Kyoto, this one traced its history back for centuries. Japanese wood-frame architecture was not meant to last, so few older buildings re- 
mained, but even the newer structures occupied the same spaces, with narrow street frontage and deep interiors. As old buildings were taken down and rebuilt, small alleys and cul-de-sacs crammed with smaller abodes filled hidden pockets away from main streets. I looked at the faces of my neighbors, who, like me, stood uneasily in front of their homes. After a moment, we slowly edged into the street and gathered at the open rear doors of the ambulance, exchanging a few words here and there in hushed, nervous voices.

I asked the man who lived across the street from me if he had any idea what had happened. He just motioned down the alleyway, saying: "If it is down that street, it could be any number of people.” His voice was low and tired, sounding more annoyed than concerned. He explained that the same thing had happened recently, just before I had moved into the area. "There are a lot of old people that live down there. A lot of old people living alone!"

He stressed the final words. It was a forgone conclusion that whoever was hurt, or perhaps dead, was most likely old and alone. In Japan, an unattended death is known as kodokushi, or "lonely death." The word kodokushi carries a tragic, melancholic tone, preserving the ambiguity around the exact association between loneliness and death. Was loneliness the cause of death, or just the circumstance surrounding it? The term itself makes way for us to reflect on the possible links between life and death, or even a death in life - a gray zone characterized by isolation, absence, disconnection, marginality, and suspense (Povinelli 2011; Allison 2013, 2018; Stevenson 2014). The ambulance lights conjured images of an everyday crisis, a spectacle that few seemed moved by, but that nonetheless demanded our attention.

\section{SPECTACLE AND THE SPECTRAL}

A lot of old people living alone. Hearing these words, it struck me that I was standing in the street anticipating the revelation of a body. I wanted to somehow bear witness to the trace of something known but unwitnessed, to give that uneasy absence some material presence. This uncertainty about why I cared or ought to have cared kept me riveted in place, as if standing in Coroners' Court, awaiting the forensic evidence to tell its story about what had happened and who was responsible.

This ethnographic moment, which I continue to unfold throughout this article, produces questions about the possibility of dwelling in uncertainty. I take dwelling to mean the emplacement of forms of habituation that produce the conditions for mutual concern and ethical possibility (Ingold 2000; Harrison 2007; 


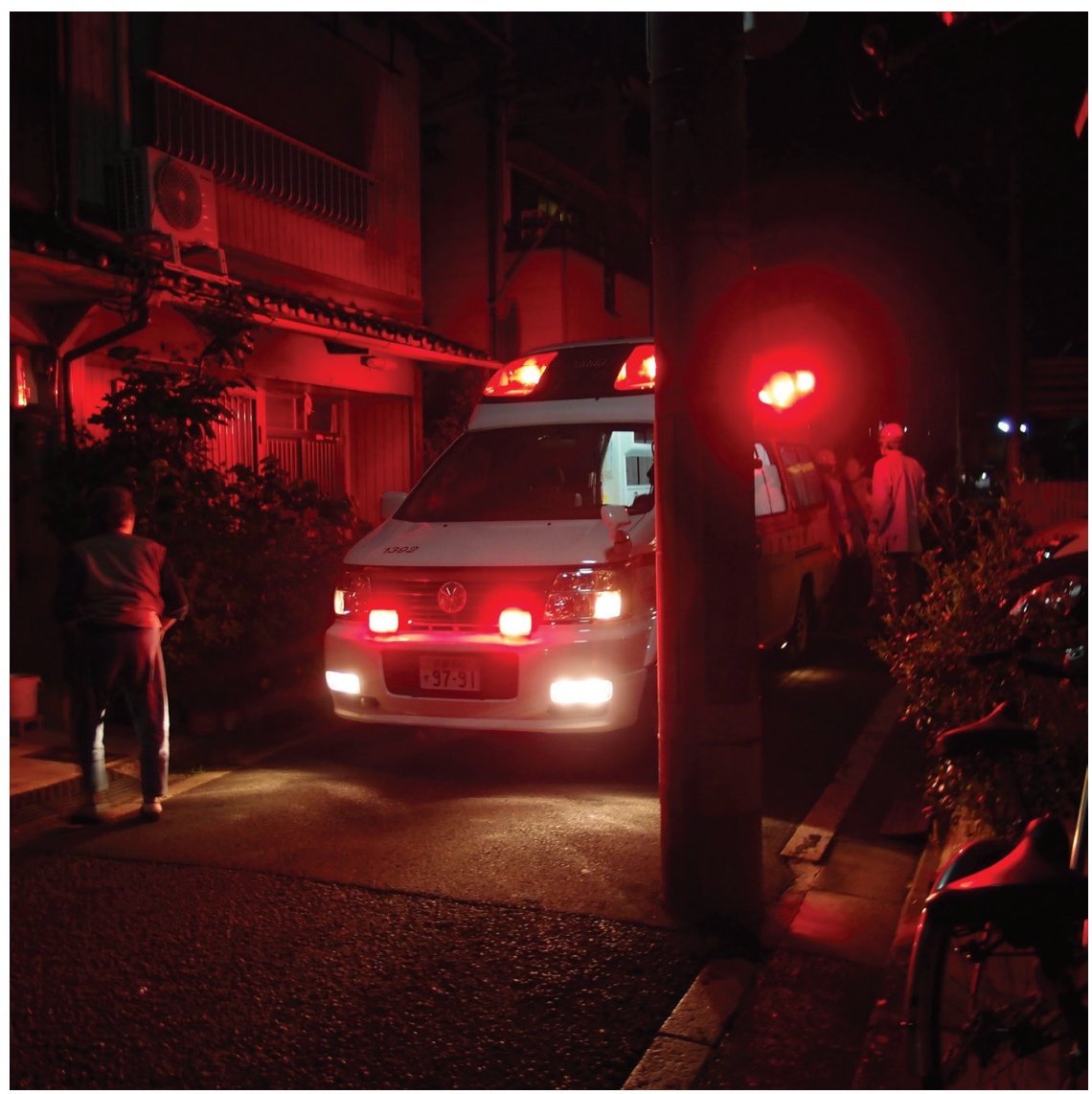

Figure 1.The street splashed in the red lights of the ambulance, as curious neighbors gather expectantly. Photo by Jason Danely.

Zigon 2014). When I refer to dwelling, then, it is in the practical material and embodied sense of being-at-home-in-the-world with others (Jackson 1995). Older people in Japan often embody this sense of dwelling, as a link between geographically based generations, living and dead, or through long-cultivated links to community life, local political activity, and leisure with friends and neighbors (Danely 2014). The regular appearance of the shadowy specter of kodokushi, however, throws the inevitability of such dwelling into uncertainty. Anxiety about kodokushi reflects concerns that the locus of dwelling and even old age itself as a terrain has become uninhabitable, despite extensive local and national investment in longterm care infrastructure (Tamiya et al. 2011; Danely 2016).

Those who die alone and unwitnessed do not readily reveal when or how they died or, in cases where no family are present, even who they really were. Yet this uncertainty is also stubbornly located in a place: the home that has become 
unhomely (Bhabha 1992). The unhomely, or uncanny (bukimi), implies both the expectation of intimacy and its disruption by something unsettling and unknown (Ivy 1995; Strava 2017; Gygi 2018). For my Japanese neighbors, the possibility that another solo-dwelling older person (dokkyo rōjin) had died just around the corner was not shocking, as it was for me, but rather produced a mood of grim dysphoria for a world that had become disarticulated from the home. What made the event unhomely was its unwitnessing, which all of us were implicated in and which placed our existential survival in question. In both kin-based forms of rootedness and postwar imaginations of middle-class domesticity (Sand 2003), homes could be thought of as conduits of relations (Daniels 2010), but with rapid depopulation, homes neither maintain family bonds nor value to the market. The private longterm care sector, supported by neoliberal social welfare reforms, has now made the home the preferred site of care provision in later life, absorbing the excess of homes and older people while extending the notion of home in narratives of the good life. This allows companies to save costs of building facilities and employ nonunionized, part-time, on-call staff, reproducing inequality, invisibility, and further isolation of both care workers and solo-dwelling older people (Danely 2016). Kodokushi mark a return of the familiar trope of the neighborhood granny-yet transformed, unsettling, unhomely, placing history's unnoticed excesses and unstable narratives at our doorsteps.

In this article I aim to explore the ways in which the homes of older adults become spaces of potential for both care and abandonment; of excessive disordered materiality and haunting spectrality; of dwelling and death. As this unruly mob of descriptors suggests, kodokushi emerge from a world "out of joint" (Derrida 1994, 22), or, more specifically, from the misalignment between a care system fashioned to accommodate working adults, private property, and insurance, and another kind of care that hinges on proximity, accompaniment, and mutuality of being (Ross 2009; Al-Mohammad 2010; Sahlins 2013). Both these schemes situate care in a place (topos/ba) but they differ in their economy (as the term is used in Derrida 1992 and elsewhere to refer to oikos, or the value of the home and its obligations of circulation and exchange). These different economies have implications for how someone might (or might not) inhabit, share, or build in this space of the home (Ingold 2000, 153; Zigon 2014, 757). ${ }^{2}$ Whereas the first scheme is positioned as a rational response to public concern over the growing cost (or diminishing value) of an aging society, the second points to other means of valuation in the social dependencies among family and community, young and old, that constitute an aesthetics and ethics of dwelling (Han 2011). ${ }^{3}$ While the current welfare stance 
holds that these two economies should mesh with one another, in practice, neither is entirely cohesive or stable, and therefore cannot fully merge with or displace the other. Instead, they together create an unhomely "place out of place" (Ivy 1995, 23), or what Azra Hromadžić $(2015,4)$ terms “semi-absences," conditions in which formal and informal care systems are ubiquitous yet inaccessible, where houses are everywhere yet uninhabitable. The presence of kodokushi indexes the uncertainty and unhomeliness arising from these semi-absences, affording an opportunity for rethinking relationships between economies and ethics in societies that have experienced rapid population aging.

In places where the value of houses and of older people appears to decline with their excess, what is the responsibility of the community to maintain connection and care? To keep them from fading into specters, or to mourn their absence? To address these questions, we might look to Jarrett Zigon's (2014) call for an "ethics of dwelling," or a moral anthropology that begins with the "ontological demand to be in the world in a certain way" such that one is "intimately intertwined with and concerned for it and its constituent parts" (Zigon 2014, 756, 757). In the context of community concerns for solo-dwelling older people in Japan, an ethics of dwelling has the potential for connecting ways of inhabiting local spaces and the relationships or ways of being-with that they produce (Ingold 2000; Al-Mohammad 2010). Yet I argue that attending to the ethical life of those dwelling alongside the specters of kodokushi, the ontological demand extends to what, after Derrida (1994), we might call a hauntological demand to attend to the ghosts in our midst and to presence them forth in some gesture of mourning. There is a resonance here with Lisa Stevenson's (2014, 15-16) notion of the "mournful life," which allows us to think about care ethics as more than just the sustaining of life, but also as the "recognition of and responsibility to the unsettling image of the other." Yet in the case of the unwitnessed death, the identity, the who that is mourned, eludes the mourners. As in the opening vignette, we were haunted by the sense that we had been responsible as neighbors and citizens for the conditions that conjured the ambulance, but unsure how to respond, caught in that moment by our own limits of dwelling alongside the other.

Mourning kodokushi, or working through the loss of past forms of dwelling, focuses instead on homes: cleaning them, reoccupying them, demolishing them, and watching houses still occupied for signs of the next death. The identity of the dead and their membership in a household (ie) forms the foundation of orthodox Japanese mourning practices, allowing the continued dwelling of family spirits in dreams and visions in ways perpetuated through ritual (Danely 2014). Kodokushi 
not only lack this intimate connection but also remain outside categories of the homeless dead who may receive rites, such as those whose remains were unrecovered due to war or disaster, or who formed part of a homeless community (Kim 2016). The uncertain identity of kodokushi, their lack of a cultural narrative of mourning, may be one of the reasons they rarely return as actual ghosts. Neighborhood volunteers, many times working closely with care managers, social workers, and even Buddhist priests, are pressed into the interstitial spaces of semi-absence opened up by between state and family, taking up this careful work of mourning. Their work conjures, transforms, and translates the spectrality of kodokushi into the language of the spirits (geist/seishin) (Derrida 1994, 9; Sakai 1997)—both the "Japanese spirit" localized through political projects of community watchfulness and the restless spirits of the old and disconnected (muen) in life and death (Kim 2016; Allison 2018). These local ethical projects expand narratives of mourning, revealing ways of acting in a world of limits (Jackson 2011).

Telling a story of kodokushi means tracing an absence (Meyer 2012), following the contours of semi-absences in spaces left behind, the affective reverberations that make one shiver if one lingers too long. This is a ghost story of sorts. That is to say, it is a story in which the ghost returns (Derrida 1994: 9-12; Ivy 1995, 22; Langford 2016, 4). In the following sections, then, I also continue to return to the dark alley filled with old people living and dying alone to illustrate the ways kodokushi exceeds the boundaries of the past or present and continues to reassert, interfere, and repeat its absence. Along the way, I engage other voices, spaces, and traces of kodokushi to situate it within my broader concerns about the possibility and limits of dwelling and care in the context of an aging society.

\section{GHOST STORIES FOR AN AGING SOCIETY}

At the back of the ambulance, the women waited, fingers clasped together behind their backs, still wearing aprons over their dresses and whispering in small groups. The men stood further back, quiet and watchful, their legs spread and sandal-clad feet firmly planted. The engine rumbled on, making it hard to talk to each other, so we stared toward the alley, looking, but not looking. After a moment, Yoshida-san, ${ }^{4}$ a woman in her early seventies, came walking slowly toward us from the alley where the paramedics had disappeared earlier. Yoshida-san was a member of the local self-governing association (minseiiin-kai) and didn't live down that alley, so it was safe to assume that she'd just been over to help out. Perhaps she was the one who called for an ambulance? The other neighbors began to ask her questions immediately, and as it turned out, it was not her, but a relative who came to visit who had made the call. Yoshida-san did tell us that the person involved was 
indeed an elderly neighbor, a man named Okura-san, and that he had fallen (taoreta). ${ }^{5}$ We nodded, unsurprised. Those who were acquainted with Okura-san knew that his wife had been hospitalized about three months earlier. Since her hospitalization, Okura-san had been living alone. I looked down the alleyway where the man lived.

Was he dead? Did others wonder this too?

$$
* * *
$$

It is estimated that about 32,000 people die "lonely deaths" in Japan each year (Tamaki 2014, 211), or about one every sixteen minutes. Sometimes the bodies of those who die unattended are discovered weeks or months after they have expired, but most are found within two or three days. In most cases, the deceased is an older person, often living alone after the death of a spouse. The number of older people living alone in Japan rose sixfold between 1985 and 2015 and continues to rise. While Japan was first considered an aging society four decades ago, ${ }^{6}$ it is now experiencing another shift, to a "mass-dying society" (tashi-shakai; Nippon Keizai Shimbun 2016). The number of deaths has been increasing each year and is predicted to peak around 2040, when 1.67 million Japanese people are expected to die, with an estimated one in four dying unattended and unwitnessed (Masuda 2015).

In Kyoto, a city with about 1.4 million residents where I conducted fieldwork, solo-dwelling older adults made up 46 percent of all households where an older person resided. ${ }^{7}$ While the main focus of my research was people caring for older family members in the city, it quickly became apparent that local volunteer services were almost entirely occupied with looking after older people who lived alone and who had significant cognitive or mobility impairments that hindered their ability to go very far from home. While paid care services were more accessible in cities like Kyoto than in outlying rural areas, a high proportion of solo-dwelling older people meant that those services were sometimes stretched very thin. This article draws mainly on interviews with paid care workers, minseiiin (commissioned community welfare officers), and ten months of volunteer work delivering meals to solo-dwelling older adults in the neighborhood where I lived in eastern Kyoto.

In 2008, the Association for the Advancement of Building Communities Where Seniors and Others Can Live Safely, a national group within the Japanese Ministry of Health, Labor, and Welfare (MHLW), published a report titled "Aiming for Zero "Isolated Deaths"' (MHLW 2008). The report, peppered with anecdotes alongside national mortality statistics, sought to outline a means of prevent- 
ing the growing social problem of isolated deaths. It began by recounting several cases, each composed with the same clinical distance despite the harrowing details. To give a sense of this style, I include a sample here:

In the spring of 2001, the skeletal remains of a fifty-nine-year-old man were discovered. Three years had passed since the death. He died on the wooden floor of the kitchen. The neighbors all believed there was someone living there since the lights had been left on and the electric meter was running. Someone coming to collect rent discovered the man's corpse. This man had divorced and lived alone. He had cut off all contact with his children and siblings. (MHLW 2008, 1; author's translation)

The story provides an intense and disturbing image of a body decaying in the house, while the rest of the world goes on, unnoticing, around it. The families of the deceased in this and other stories recounted in the document are represented as neglectful or absent because of the implied social failings of the deceased. They failed to connect. Like campfire ghost tales, these anecdotes deliver a little morality along with the fright, propelling the rest of the document into its impassioned appeal to eliminate "tragic" scenes by mobilizing the community to build caring relationships, to "greet each other with a pleasant voice," raise "community consciousness," and make watchfulness a part of "everyday life" (MHLW 2008, $11-12)$.

Kodokushi became a popular media topic in Japan in part because of the sensational images they produced. This held especially true in the aftermath of the Hanshin earthquake of $1995 .{ }^{8}$ Many of the survivors, relocated to residential apartment blocks (danchi), became solitary not just for reasons of age and infirmity but also because the residences did not provide significant opportunities to socialize or build ties for the dislocated refugees. Some older people, suffering from inadequate postcrisis support, died and were not immediately discovered. After a national outpouring of aid, this lonely end stood as a haunting reminder of the challenge of caring for others and raised anxieties about social and family disintegration (see Morioka 2012) amplified in the postbubble recession of the early 1990s. Anne Allison $(2013,8)$ describes this sense of internal alienation and precarity in the context of late liberal, post-3/11 Japan as "liquefied," and, echoing Derrida (1994, 21-22), haunted with a sense of "being out of place, out of sorts, disconnected” (Allison 2013, 14). 
My neighbor, Okuda-san, whose fall had brought the ambulance to his house, would be considered a typical case of someone whose dwelling had become uninhabitable. In this case, it was the minseiiin who stepped in to contain the narrative. Since the establishment of the national People's Welfare Law in 1948, unpaid community welfare workers, selected because of local standing and interest, have looked after the most vulnerable, including disabled persons and the elderly. As local extensions of the Ministry of Health, Labor, and Welfare, minseiiin volunteers act as intermediaries between state-led initiatives like the "Aiming for Zero Isolated Deaths" report and communities, playing a crucial role in reinforcing images and ideas about kodokushi and the crisis of social disconnection by transporting and translating information between formal governmental bodies and local neighborhood associations. Before approaching the home, then, we must first understand how minseiiin simultaneously construct local community life and its opposite: the lonely death.

When talking to local minseiiin about incidents of kodokushi, all strongly expressed how important it was to "watch over" solo-dwelling older people. At the same time, they had little sense that their efforts were actually able to prevent kodokushi. One reason they gave was the restrictions on entering houses. Community leaders considered the house both a site of surveillance and an obstacle to direct witnessing. Since most houses in the urban residential areas of Kyoto were closely packed together, facing directly onto the street, it was easy to see and hear what was going on when people were active. Because of this exposure, however, most people took care to keep shades and shutters closed - it was also easy to go unnoticed in plain sight.

"We are all scared [of kodokushi]," one minseiiin told me, adding that she visits the older solo-dwelling adults once a month to check on them. "But since they might die at any time, I ask neighbors to stay alert and contact me if anything seems amiss." Other minseiiin echoed these comments, saying, for instance, that it is the "main job" of the minseiiin to "help people before they become kodokushi," by dropping in and watching over (see Figure 2). "We're not really allowed to go into homes and check on people, you see," one minseiiin confessed, "but ordinary people, well, they can do as they like, so we can ask them to check on so-and-so if we are concerned."

Since the frail elderly (or their decaying bodies) remain hidden from view, the house stands in for them. A skillful minseiiin will be able to gently persuade or cajole neighbors and friends into help keeping watch on the signs of possible kodokushi, such as untended plants or messy entranceways with stacks of mail. Of 


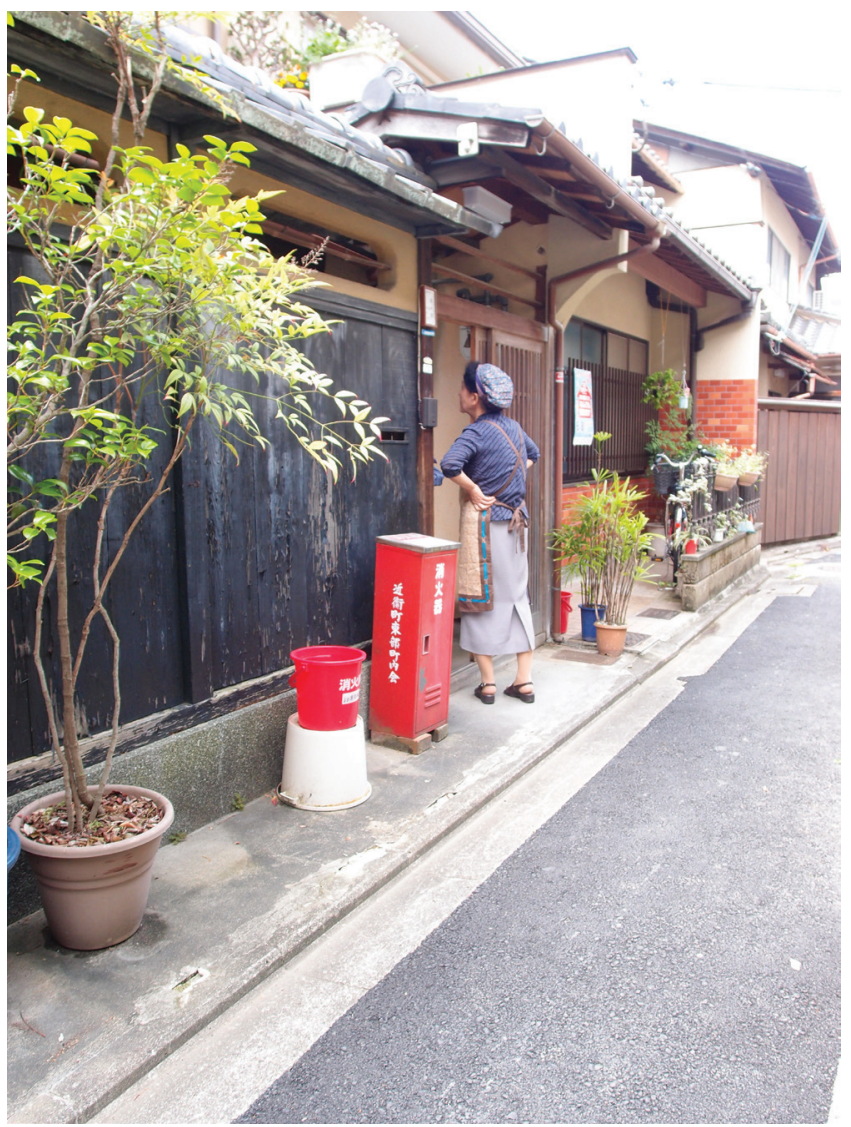

Figure 2. A visit from the minseiiin rarely crosses the threshold of the home of the solo-dwelling older person. Photo by Jason Danely.

course, as the case of Okura-san indicates, even when it looks as though someone might be very vulnerable, there is little that ordinary community members or even minseiiin feel they ought to do.

The city requires community social welfare volunteers to publicly report any kodokushi that has occurred in their district at monthly meetings, with representatives from other areas present. There are no direct repercussions, financially or otherwise, and while no one likes to report a kodokushi, it is understood that it could happen to anyone. As one minseiiin put it:

It's not kodokushi prevention, [it's] just watching over (mimamori). People with bad luck are going to become kodokushi. So in order to make sure that doesn't happen, we watch over them. But we never know when it is going to hap- 
pen. No matter how much we look in on them, if they don't have any family around, we can't help!

This kind of distance and resignation surprised me initially, but after several similar conversations with care professionals, it became clear that care needs for solodwelling older people in particular were on a scale far beyond what minseiiin could reasonably be held responsible for. The immediate effects of kodokushi, the gossip and stories that circulated after the ambulance had left, do, however, affect the minseiiin and their ability to maintain a symbolic role as wards of overall community health, vitality, and spirit.

Why continue to make these efforts to watch over solo-dwelling older people if you cannot prevent unwitnessed deaths? This question led me to reconsider acts of watching over as not only instrumental, preventative gestures of care but also as the basis for recognizing solo-dwelling older people as the "unsettling image of the other" (Stevenson 2014, 15), subjects who, as the term unsettling suggests, are adrift, haunting, and at the edges of dwelling. At stake in efforts to integrate the solo-dwelling older person, then, was the ethical and aesthetic sense of dwelling in the community. ${ }^{10}$ Deaths that occur with family or care staff present are orderly. But kodokushi, as one minseiiin put it, "is a mess," continuing:

There are police, and reporters arriving - and then what would people think? That minseiiin-san wasn't doing anything! So to make sure that doesn't happen we have to constantly be vigilant. First, we look to see if their plants are $\mathrm{OK}$, if it looks like they haven't been tended in a while. Or we look to see if they have been getting their mail. We can't go around to everyone and be ringing doorbells.

Watching over (mimamori) provided a means of creating a public image of the solodwelling elderly person. Its mode of communication was in the register of what Shunsuke Nozawa (2015, 388) identified as "phatic mereness," where gestures of connection leave momentary traces, or trace momentary encounters with others, as absent as it is present:

The moment of effacement may create an imaginative worlding, and summon anew "the vitality of something that refuses connections." A fuller copresence may be just a dream, a hoax. People will still die alone. But a reckoning of alterity might allow them to live and die believing their life and 
death will be notable to someone, a you, any one of you, on the other side of the channel. I know you are not here, I just want a hint, a sign that you are alive and waiting for me-not even that. (Nozawa 2015, 395)

Nozawa reminds us here not to fully close the door on the possibilities of connection (en, tsunagari) often mobilized in kodokushi-prevention narratives, even when it appears that there is little to be done. Make no mistake: the concern of community leaders expressed a genuine compassion for lonely and isolated older people, even if cultural conventions of civility mediated their concern. To present themselves as a community of concerned others, they could only gesture at connection, creating a space of indeterminate potential, imagination, and endurance.

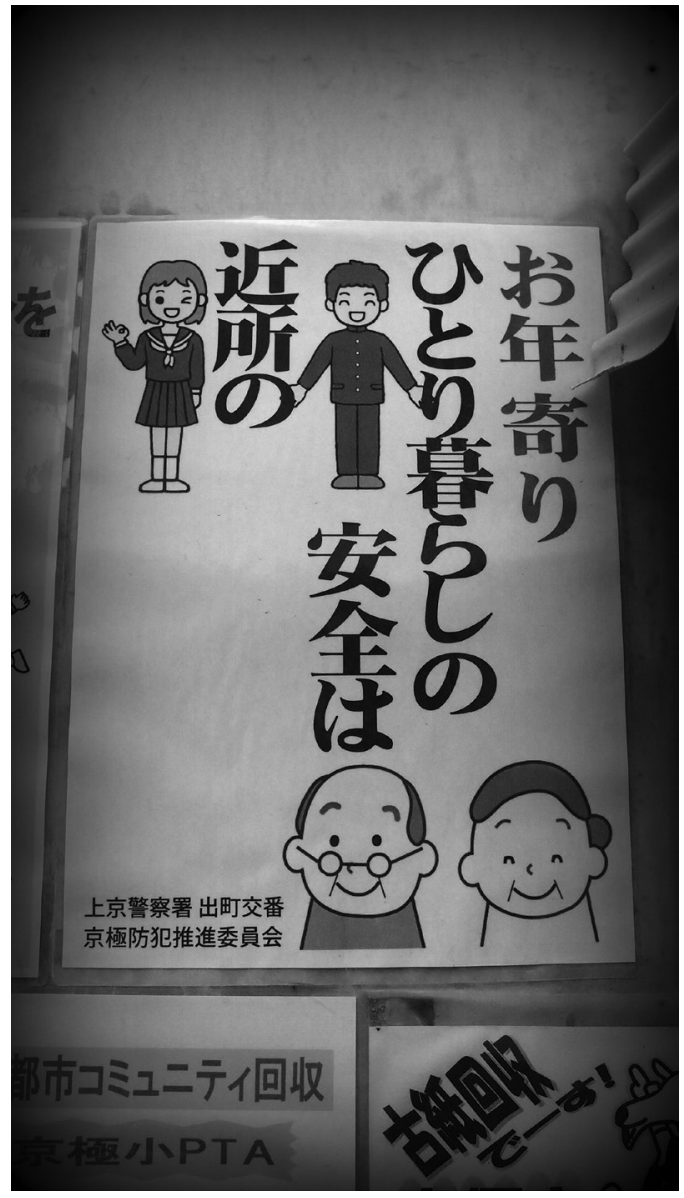

Figure 3. An impression of phatic mereness. A poster reads: "The safety of solo-dwelling older people is the neighborhood's [safety]." Schoolchildren greet a smiling older couple at a distance, without facing them directly. Photo by Jason Danely. 
A political ethic of watchfulness like that adopted by minseiiin requires looking at techniques of envisioning and the images envisioned. Images of kodokushi are described in policy documents, case studies, popular news reports, documentaries, and posters. They are the spectacular images that obscure less perceptible and more widely distributed specters of social isolation and abandonment of older people. Community volunteers and care managers make drop-in visits, and their observations often make their way through the local community as gossip. When I asked about stories I had heard with the minseiiin and care workers I knew, they responded with visible expressions of pity and disgust as well as a kind of moral talk that tried to contain this affect and provide some resolution to the unease it provoked. But press just a bit further and one also found an undercurrent of resignation and even indifference.

Deaths that go unobserved or unnoticed are viewed retrospectacularly as messy and disorganized, casting a shadow over other community efforts to instantiate connectedness and belonging. ${ }^{11}$ As such, they motivate and mobilize community efforts to manage the end of life. The goal is not to prevent death, but to prevent a messy death.

\section{HAUNTED HOUSES}

I had met Okura-san before, but rarely saw him outside of his home. The last time I had seen him was two weeks earlier, when I accompanied another volunteer to deliver a lunchbox as part of a community service to older people living alone. We met him at his front door where, after we announced our arrival several times, he appeared, disoriented and exhausted. The other volunteer didn't look too concerned, but I was relieved and smiled as I handed him the lunch. I asked if he was getting along since his wife had been away at the hospital, to which he offered a list of complaints. He felt worried because she was reaching the three-month limit on her stay and would need to be transferred to another hospital, even though she was still in a coma. He told me that he takes a taxi to the hospital almost every day, sometimes bringing a CD player with music she enjoys. The other volunteer, eager to move on, prompted Okura-san for the lunch fee. We ended up asking him several times, and each time he would disappear into his darkened house and return to the door with a look of surprise, having forgotten the amount or what he was looking for in the first place. We ended up just telling him that we'd pick it up when we collected the lunch box later. What else could we do? There were a lot of other meals to deliver to older people living alone.

In hindsight, I wondered if we shouldn't have done something more. What was my responsibility? 
Around the end of the nineteenth century, when a Japanese person spoke of "home," they were most likely referencing an environment, a family group, or even a set of practices (Sand 2003, 25) rather than a building set apart from others. Throughout Japan's rapid national modernization process in the early twentieth century, however, a radical shift occurred in the meaning of home and the domestic, in conjunction with other material, architectural, and economic changes. Over the second half of the twentieth century, rapid urbanization and increased mobility linked to infrastructure and a stable employment system created opportunities to live independently of the family home. In the 1950s, the vast majority of urban dwellers were renting, but as the economy began to prosper, home ownership rose sharply to around 60 percent in the 1960s (Izuhara 2015, 179), where it remains today.

In the era of Japan's post-World War II so-called economic miracle, having one's own home became an emblem of aspirations, a "my-homeism" inspired by hope and underwritten by debt (Allison 2012). Since the postbubble recession of the 1990s, however, a phenomenal growth in "empty homes," or akiya, has occurred. At first, these were not the newly built homes of the suburban "bed towns," but rather older homes that were not inherited, where aging parents stayed, then abandoned when the old people died or vacated. A landlord in a semirural area outside of Tokyo told me that he had noticed a rapid increase of both akiya and kodokushi over the past decade as the town's population grew older, and that even among his rental properties, two or three cases of kodokushi happen every year. He not only has to bear the cost of cleaning out the property afterward but said that he also always tells prospective renters about the fate of the former tenant, offering a discount on their rent.

As I walked down residential streets of Kyoto with informants, some commented that they could tell if there were a lot of older people in the neighborhood by the number of shuttered and empty houses. Sometimes these looked as one would imagine a haunted house: discolored walls and doors, stained curtains and peeling paint, vegetation wildly creeping across the facade (see Figure 4). At other times, however, the akiya were hardly noticeable, blending in with the other tightly packed houses that appeared similarly vacant except for a few potted plants by the door. When I volunteered delivering meals to solo-dwelling older people, the empty houses became a frequent topic of conversation. The circulation of knowledge about former inhabitants enhanced my sensitivity to the small details 


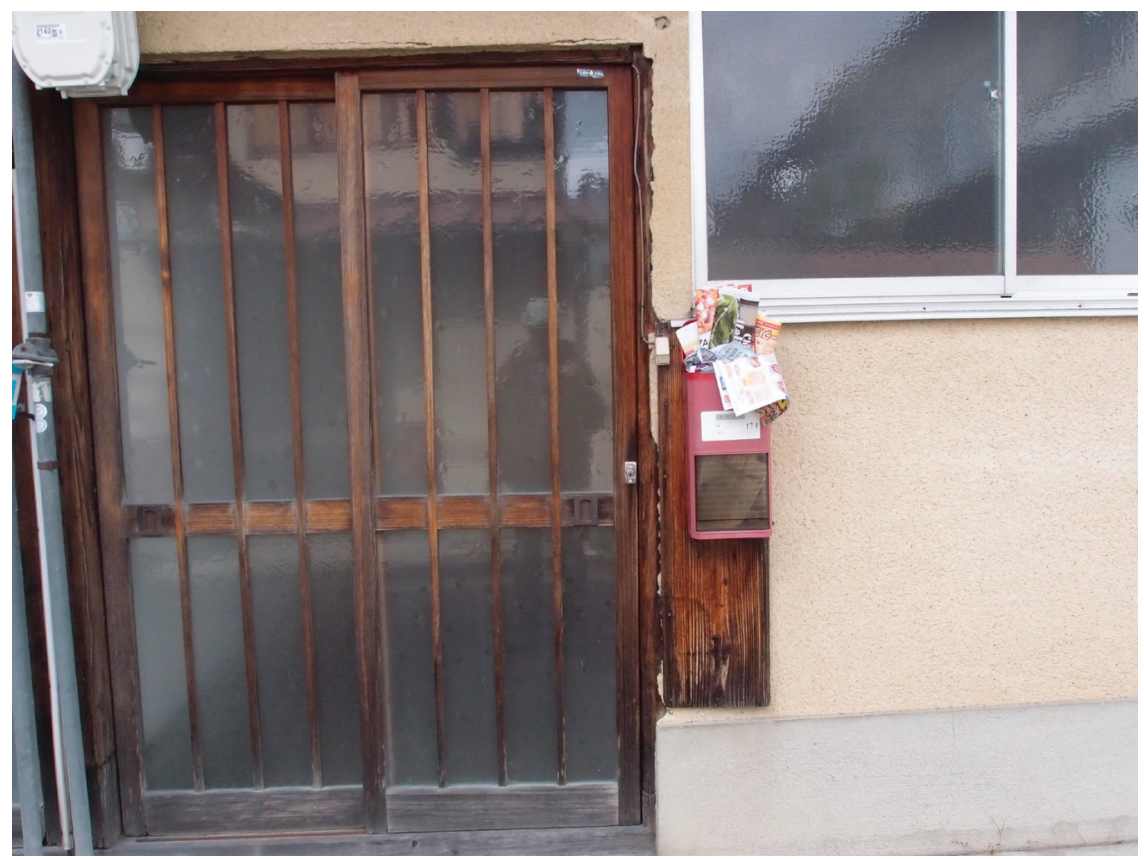

Figure 4. Akiya house, with leaflets overflowing the unused mailbox. Photo by Jason Danely.

that distinguished the aesthetic presence of these akiya, sometimes only apparent after time had passed. In some cases, the individuals to whom we delivered food were like islands left by the rising sea of akiya all around them.

Although the existing housing stock is greater than the total number of households in Japan, public funds continue to be used to build new units in a neoliberal strategy to stimulate the economy (Izuhara 2015, 186). As a result, in contrast to other countries where home ownership constitutes an important welfare asset for older people, Japanese homes are left without refurbishment and lose value. Already in 2014, the number of akiya nationwide exceeded 8 million, or 18 percent of the houses in Japan (Sobel 2015). In the same year, there were more than half a million names on waiting lists for entry into long-term residential care and nursing homes. The contrast between the sea of empty houses and the excess of older people seeking care homes is striking, yet a similar inhibition of dwelling characterizes them both. Kodokushi and akiya, like ghosts and haunted houses, are the enduring subjects of mourning in this late liberal landscape.

"All the empty houses, that's the biggest problem," said one shop owner I spoke with when I mentioned my interest in aging. "The children don't want it, but the parents keep thinking that they can give it to the kids. But by the time they die, the house is worthless! The kids sometimes demolish the house, and then 
build two or three separate lots on those spaces." Since visual pollution regulations prevent the building of large high-rise apartment blocks around the center of Kyoto, and because of the high cost of demolition, however, many successors may not be able to convert houses after the owners pass. To the shop owner, this was not just economically wasteful, but also constituted a persistent image of a decaying landscape where bonds of kin and community were stretched to breaking. The akiya tend to bring down the prices of homes in the area, but more than that, they serve as potent reminders of the limits of dwelling. Like abandoned graves of the unconnected spirits (Danely 2014, 107), the akiya are seen as messy, disruptive, and dangerous; they are difficult to mourn.

If the image of economic success had been home ownership, then the image of failure was not only the messy death but also the messy house (Allison 2018; Gygi 2018). Cleaners of kodokushi houses, covered head to toe in protective suits and ventilators and picking through soiled remains, bear an uncanny resemblance to the crews tending to the dangerous radioactive waste of the Fukushima reactor damaged by the earthquake and tsunami on 3/11. Similar images of Fukushima survivors and the kodokushi cleaners praying for the spirits of the dead amid life's wreckage, dressed in mortuary-white protective gear, have been widely circulated by the media in Japan and abroad.

These images, like those of "rubbish houses" (Gygi 2018), echo the unhomely between mourning sites of environmental catastrophe and intimate entropy, dramatizing the potentially contaminating effects of messy deaths for both the spirits and the survivors. But specters must fade back into invisibility, quietude, into the inner recesses of the home that traps things and people rather than facilitating flows and relationships. In one case, for example, Nishida-san, a minseiiin living in central Kyoto, told me about discovering the body of a woman who had died days earlier alone in her home. After alerting the police and confirming that the woman had no next of kin, Nishida-san called other local community members to help clean the mess made by the leakage of bodily fluids. As they lifted up the tatami mats on the floor, they discovered a hidden stash of money (hesokuri). When I first wrote about Nishida-san's discovery (Danely 2014, 146), I treated it merely as an example of the ways older people express concern and perform ritual services for the abandoned. When she told this story to me again a few years later, I asked about what had happened to the money, to which she replied:

We laughed and said we'd all divide it up! Even the police said that he'd take some first! [laughs] But the police took it and counted it and did everything 
properly. I really feel bad for people with no family. The end was coming and all she had left was money. She didn't have anyone to give it to. No children, no siblings. So we just asked for enough to cover the cost of a small funeral, cremation, and some sort of memorial. The police just took [the money]; I don't know what happened in the end. They didn't give any to the minseiiin to say thank you for all of your hard work!

Here again, the absence of family and the messy corporeal remains revealed a hidden accumulation of money that remained trapped rather than circulated. The work of the minseiiin, however small, allowed some of that money to flow back into the work of relationship building through the funeral, to resettle the spirit and contain the unsightly spectacle.

Nishida-san's story, like that of the professional kodokushi cleaning crews, shows how the homes of solo-dwelling older people have their own pungent "ecology of sensibility" (Hankins 2013); they are anything but empty. She described another case of kodokushi where funeral instructions and money were set aside for whoever found the body, but in most cases, she only found a mess: unpaid bills, soiled underwear, the wrapping of cheap instant noodles. These are unhomely homes that bear the stains of a person beyond dignity, beyond dwelling. Like the police response after kodokushi, empty houses continue to produce political and existential consequences for the community and those charged with watching over it.

Inge Daniels (2010) described the ways in which houses in Japan at once appear structurally impervious and opaque, shuttered and gated off from the community, yet also surprisingly porous, as friends and neighbors find ample opportunities for watching over and dropping in. These flows happen because of the social and ideological infrastructures of the house. Japan's universal and mandatory LongTerm Care Insurance (LTCI) system has become part of this infrastructure, regulating the flows of dependencies, bringing carers into the home or keeping them out. Several informants told me that it was easier to access care services when living alone, since co-residing family reduced eligibility for LTCI benefits. Many people, however, are hesitant to become a burden on welfare services, even when they are eligible. As LTCI displaces the flows and porosity of family and community, it also creates semi-absences that render the solo-dwelling older person vulnerable.

Home-modification and contracting scams are some of the most common forms of fraud targeting solo-dwelling older adults. In one recent case, a man posing as a contractor in Kobe city defrauded a solo-dwelling woman with dementia 
for 6.8 million yen (around US\$637,000) between 2013 and 2014 (Asahi Shimbun 2018). These schemes differ from other fraud targeting older people because they include face-to-face home visits; in about half of all such cases, the victim is over seventy (compared to one-quarter of the cases of store-based contractor fraud; National Consumer Affairs Center of Japan 2013, 10). These scams are particularly devious because they take advantage of the symbolic significance of the home on at least three levels. First, home is a place where one will grow old and die. Scams often promise to make older homes fit for older persons considering a future where they will need more supportive modifications, and so home improvement becomes a means of asserting autonomy over aging, even as it leaves them more vulnerable to predatory schemes. Second, the unnecessary repairs are often infrastructural, as was the case with one solo-dwelling neighbor in her nineties, who was scammed by a contractor claiming that she needed to urgently repair plumbing and hidden water damage beneath her floors. Other scams target roof repairs, since loose tiles cause damage to surrounding houses during typhoons. Both cases leverage a sense of fear and responsibility by making these imaginary infrastructures visible and ethically laden. Third, they take advantage of the social isolation of the older person by providing a rare chance for recognition and generosity; older people want to give, and may find meaning in some kinds of loss. As Nozawa $(2015,375)$ notes, these scams fill "security holes" of indifference with interest, but in the end, this interest is at best a costly fantasy, and at worst, dangerous abuse.

Those watching over and dropping in on solo-dwelling older adults might try to catch these sorts of abuses and guard the older person's fragile state of dwelling for as long as they can. But too often abuse remains hidden within the home, itself more of a specter than a public spectacle.

\section{EMPLACING AND EMPLOTTING DEATH}

Somehow one of the women in the gathering surmised that the ambulance had been called by Okura-san's son, who had by chance been visiting that day. Okura-san was soon carried, strapped to the stretcher, into the ambulance, alert but confused and disheveled. His black nylon socks were bunched awkwardly and his feet laid askew, one leg slightly bent up. This detail broke the smooth performance of the paramedic crew, who, like the puppeteers of Japanese bunraku theater, seemed to disappear in their quiet, efficient movements. I was riveted by the man with the rumpled socks.

Okura-san's son soon joined the paramedics, carrying a bright green nylon duffel bag and briefly apologizing to all of the neighbors as he climbed into the ambulance next to his father. As the door shut, one of my neighbors, a woman with thick gray hair and large 
glasses leaned over to me, whispering: "I am eighty-eight years old. Isn't it terrible that people here are living too long? There are no young people in our neighborhood anymore. . . . No young people in Japan . . ." She turned and walked back down the street alone before I could respond.

For the spectators, an event like a neighbor's fall has significance that reaches beyond the house, beyond the neighborhood, enveloping an entire nation: no young people in Japan. Young people, or so I read her tone, do not die like this. Even though this scene in the alleyway did not involve the actual event of death, I could not have been the only one who imagined it. The event asks the questions of mourning: whose body and where is it? For my neighbor, the disappearance of the body into the ambulance signaled a movement from the social body of the community, bonded through the phatic labor of volunteers, and the body politic, marked as much by uniformity and order as by a sensorial spectacle of emergency (Scheper-Hughes and Lock 1987).

Many ethnographies have already discussed the significance of place, and especially of the home, in regard to attitudes and practices surrounding death, dying, and mortuary ritual in Japan (e.g., Long 2004; Connor and Traphagan 2014; Danely 2014; Kim 2016). Most of these note that historically, the embodied copresence of intimate others to watch over the dying person is critical; the same expression, mimamori or mitori, is used both for keeping a death watch and for watching over solo-dwelling older people. Around 75 percent of deaths in Japan occur in hospitals (MHLW 2017b), where the patient is not given the option of returning home before they die.

One explanation for this, as mentioned earlier by a minseiiin, is that for the bereaved family, the death at home, even when the body is discovered quickly, can become something like the spectacle of kodokushi, with police and medical staff called to scene. Doctors and medical staff sympathetic to bereaved families sometimes become complicit in avoiding this spectacle by clever ways of emplacing and emplotting death, ${ }^{12}$ staging a bureaucratic performance that transforms the haunting, messy death to one that is good and orderly. For example, one doctor told me:

A lot of people call the hospital at the last minute to avoid a big scene. My advice is that if someone dies at home, you should call the doctor you trust. If I get a call, sometimes in the middle of the night, I'll tell them to hold on and clean the body. Then I'll come later and do the examination and take care of 
the paperwork. That way the family can avoid dealing with the police. This happens a lot!

These efforts to avoid a suspicious death were performed not only for those who died at home but also for older persons in geriatric care facilities. One nurse at a geriatric institution (rōjin hoken shisetsu) told me that even when someone had clearly died, staff would call the ambulance, and the paramedics would go through the motions of trying to save the person or examine them as if they were still potentially alive until they arrived at the hospital. Then, on arrival, doctors could pronounce that the person had died at the hospital rather than at a care institution. In examples like these, bureaucratic procedures and documentation lent themselves to a process of emplacing and emplotting death to produce conformity to both legal requirements and an ethics of dwelling.

As with the minseiiin, a general consensus existed among the medical professionals I spoke with that preventing kodokushi entirely was absurd and that the good death at home, surrounded by family, was, as one nurse put it, "nothing more than a fantasy." There was no such thing as Kodokushi Zero society. Middle-aged people I spoke with thought dying alone at home was more desirable than dying in a hospital, which remains associated with the frightening image of life-support systems of wires and tubes that Japanese people refer to as "spaghetti syndrome." But they also realized that despite personal preferences, the end of life in old age was very difficult to control (Long 2004). In the context of overburdened care institutions, there is little left to do but live under the occasional gaze of the minseiiin and nosy neighbors and hope to dwell unto death without becoming trapped in one's home.

One case manager described the "trap" of home this way:

People are going to need help, and if the services are not there, they'll go to a hospital, then to a geriatric institution, then to a home or to older persons' housing, where you can heap on all sorts of services. Then you're in your own place but you're imprisoned in solitary confinement [zashikirō] . . . we're becoming a dying society. There won't be the family there to watch over [the dying], or the family will be old themselves. We're worried about what lies ahead [Saki yuki fuan]. The country hopes people who have dementia or are bed-ridden die in the community, receiving care from local groups, so they don't have to use hospitals and care facilities. They tell the local people to do something about these people. People living alone are increasing, kodokushi 
and things like that. So the community is told to take care of these people, watch over them [mimamorinasai].

This care manager is rightfully concerned about what lies ahead. The last major revision of LTCI in 2017 (MHLW 2017a) raised fees and overall personal spending limits while promoting support for independence (jiritsu shien) and rehabilitation. Most of the older adults and family caregivers I spoke with expressed deep concern about this change and about what it will mean for the quality and kinds of care available for older adults living alone. "The government is just throwing all of this on our backs," complained one minseiiin. "They say you take care of these old people, but we don't know how to be a community like that." Statements like this suggest not only an ethos of disinterest or resignation but also a struggle to mourn in meaningful ways in a "mass-dying society" where care economies of home simultaneously depend on and conflict with the tenuous bonds of community.

\section{CONCLUSION}

Kodokushi insinuates itself into the social imagination as a constant haunting presence, a banal tragic ethos, like the unsettling undertone felt when an ambulance stops outside one's door. It haunts the borderland between the state and neighborhood, public and private, just beyond the touch and watch of the community. In maintaining this blurred boundary zone, the houses that isolate solo-dwelling older people are hidden in plain sight. They were there all along, as both an ideology and a structure of care.

This article has examined the ways care, and particularly community-based "watching over," is employed to imagine the unwitnessed deaths of solo-dwelling older adults. I have argued that the construction of the kodokushi narrative in minseiiin reports, death certificates, welfare documents, cleaning rituals, and everyday gossip provide an opportunity for mourning that attempts to restore the possibility for an ethics of dwelling and witnessing. Narratives that try to make sense of kodokushi as a local event, as well as an index of an age of national decline, prompt feelings of both crisis and resignation. The excess of lonely older people and houses without value, however, continues to produce semi-absences for the specter of kodokushi to reappear and cast uncertainty over this possibility.

An economy and ethics of dwelling raises questions about the material environments that people dwell within. People who become kodokushi are defined paradoxically by their inability to fully dwell and their inability to do anything but linger on alone in their home. Houses are not the cause of kodokushi any more 
than automobiles are the cause of traffic accidents. However, their place in the economic and political landscape of Japan's history since the mid-twentieth century has intensified their significance as places of hope and aspiration, care and community belonging. The narratives and images of kodokushi exist alongside those of the empty houses that haunt an aging, postbubble Japanese society like the brittle husks of great cicadas. In the absence of a witness, these ghosts bring forth a hauntological demand to mourn the unsettled other, to emplace and emplot them in ways that can counter the spectacle.

It is difficult to picture what kinds of changes the next decades of Japan's aging society will bring. There has simply never existed a society where 40 percent of the population are over sixty-five and are expected to live well into their nineties. The death rate will continue to rise, as will the numbers of kodokushi, since institutions will not have the capacity or resources to otherwise deal with the aging population. Japan will continue to be a place for the work of mourning, where images will play a central role.

Throughout my own narration of kodokushi, the solitary subject of death has remained quiet. Perhaps it was this silence that led to his invisibility even before death. He didn't communicate, didn't know how to narrate his own ending. We are left to imagine, as my neighbor did, that his fate is also ours, or even Japan's. The specters still ask: who is responsible? We are left with a glimpse of an oddly rumpled sock disappearing into the back of an ambulance, and then, with ourselves.

\begin{abstract}
Demographic and policy changes in Japan during the first decades of the twenty-first century have resulted in significantly more people growing older and dying alone, especially in densely populated urban centers. As the national Long-Term Care Insurance system continues to promote community-based elder care despite weakened family and neighborhood bonds, the home has become an intensified space of care as well as a potential zone of abandonment. This article considers these divergent potentials of home and their implications for thinking about the material, ethical, and aesthetic limits of dwelling as embodied in the specter and spectacle of the lonely death (kodokushi). Such deaths and the empty houses they leave behind index other forms of loss emerging from intertwined histories of the family, welfare, and housing and construction policy. I argue that the connection between local experiences of aging and death and national policies can be found in mediating images and narratives of mourning, which seek to locate and make sense of the inability to dwell. Approaching unwitnessed deaths as specters at the limits of dwelling allows us to move beyond the shock of lonely death and draws our attention instead to the links between caring,
\end{abstract}


mourning, and the home in an aged society. [dwelling; community care; social isolation; old age; lonely death; Japan]

\section{要約}

21 世紀前半の20年間における日本の人口動態と政策の変化の結果、特に 人口密集した都心部で一人で老後を過ごし、亡くなっていく人々の数が著 しく増大した。家族や近隣共同体の絆が弱まっいるにもか力わらず、国 の介護保険制度が地域を基盤とした在宅高齢者介護を促進し続けている ため、居宅は介護の場となるだけでなく、潜在的な放棄の場ともなつてい る。この記事では、これらの居宅の多様な可能性を検討する中で、孤独死 の幻影(specter) と光景(spectacle)が具現化した場としての住まい(dwelling)の物 質的、倫理的、そして美的な限界について考察する。孤独死亡残された空 家は、家族や福祉、住宅、そして建設政策などが絡み合った歴史から生じ る社会的な䘫失を写し出すのだ。こで議論されるのは、地域における高 齢化および死の経験と国家政策との関係が、居住(dwell)不可能性を見定 め、理解しようと努める哀悼のイメージや物語を仲介することで見出しう るということである。誰にも目撃されることのなかった死を、住まいの限界 に現れた幻影ししてアプローチ寸ることで、孤独死のショックを乗り越え、 高齢化社会における思いやり之、衣悼、そして居宅との関連性に注目する ことが可能となる。[住まい; 地域厅ア; 孤独; 老年期; 孤独死、; 日本 $]$

\section{NOTES}

Acknowledgments I thank the Cultural Anthropology editorial team and the anonymous reviewers for their generous, thoughtful, and encouraging input on this article. Research for the article was supported by the Japan Society for the Promotion of Science Short-Term Postdoctoral Fellowship (PE13251).

1. Some policy documents refer to such deaths, somewhat euphemistically, as koritsushi (isolated deaths), which implies a degree of independence and autonomy. The journalist Takeshi Yabe (2012) has argued that this form of death is not problematic in the United States, and is only a problem because of an antiquated Japanese social ideology that unfairly stigmatizes older people living alone.

2. While an extensive body of work exists on topos and theories of territory and place, I limit myself here to the context of Japan. Two major contributors to rethinking topos in the Japanese context are Nishida Kitarō and his student, Watsuji Tetsurō. While there are differences between the two, both shared a contention that the Heideggerian phenomenology of being and time did not sufficiently develop notions of relationality $(m a)$ or place/environment $(b a)$. These philosophers, who draw generously from Japanese Buddhist perspectives, have had a strong influence on cultural aesthetics and its use of empty spaces, pauses, and elipses that produce a consciousness of the radical interdependence of subjectivity and milieu.

3. In this sense, we might say that these map closely to Ferdinand Tönnies's use of Gesellschaft and Gemeinschaft, or Annemarie Mol's (2008) contrast between the logic of choice and the logic of care. Here, I want to emplace these logics in the historically specific and culturally constituted spaces of the house/home.

4. All names used in this article are pseudonyms. 
5. The word taoreru is ambiguous in this context. It is sometimes used as a euphemism for death, but it may also simply mean that the person collapsed. As the situation remained unclear, this was the most she would tell us, and no one asked further.

6. In 1970 Japan officially became an aging society, with 7 percent of the population over sixty-five. As of 2017, about 27 percent of the population is over sixty-five, making Japan the world's first "super-aged society" (chōkōrei shakai).

7. Of 260,434 households with at least one older person residing, 120,294 were composed of only one person, according to the October 2015 census of Kyoto.

8. Nozawa $(2015,375)$ notes that the word kodokushi began appearing in newspapers around 1970 and grew more prevalent throughout the 1980s.

9. $3 / 11$ refers to the triple disaster (earthquake, tsunami, and nuclear meltdown) that occurred on March 11, 2011 in northeast Japan. This disaster and its aftermath precipitated an urgent desire not only for justice to those directly affected but also to mourn and reflect on social disconnections and the potential for unity in the face of tragedy.

10. I use aesthetic here to acknowledge the ways kodokushi, and the vigilance toward it on the part of minseiiin and others in the community (seken), is an intensely sensual experience. As Joseph Hankins (2013) has argued, Japanese social differences are reproduced within an "ecology of sensibility" linking levels of interpretants (e.g., community, local welfare officials, minseiiin volunteers) through affects and embodied senses in ways that undergird logics of exclusion and stigmatization.

11. I am grateful to the anonymous reviewer who suggested this brilliant phrasing, and for pointing out the chronotopic and hauntological dimensions of the spectacle of kodokushi. The unwitnessed death might be suspected or sensed, but remains quiet and hidden, only spectacular after it is discovered.

12. The notion of emplotment is borrowed from Paul Ricoeur's (1984) poetics of history, time, and narrative. Emplotment describes the ways that tactics of mediating agents (doctors, volunteers, community leaders) allow those agents to manipulate mediating elements (documents, family members, bodies) to create a moral outcome "as if."

\section{REFERENCES}

Al-Mohammad, Hayder

2010 "Towards an Ethics of Being-With: Intertwinements of Life in Post-Invasion Basra.” Ethnos 75, no. 4: 425-46. https://doi.org/10.1080/00141844.2010.54439 4.

Allison, Anne

2012 “A Sociality of, and Beyond, 'My-Home' in Post-Corporate Japan." Cambridge Journal of Anthropology 30, no. 1: 95-108. https://doi.org/10.3167/ca.2012.300109.

2013 Precarious Japan. Durham, N.C.: Duke University Press.

2018 "Not Wanting to Die Badly: Facing the Precarity of Dying Alone in Japan." In Ethnographies of Waiting, edited by Manpreet K. Janeja and Andreas Bandak, 181201. New York: Bloomsbury Academic.

Asahi Shimbun

2018 "Ninchishō no josei kara 6800 man yen sagi shita utagai otoko wo taihō [Man Arrested on Allegation of Defrauding Woman with Dementia of 6.8 million yen]." News, March 7.

Bhabha, Homi

1992 "The World and the Home." Social Text, nos. 31-32: 141-53. https://doi. org $/ 10.2307 / 466222$.

Connor, Blaine P., and John W. Traphagan

2014 "Negotiating the Afterlife: Emplacement as Ongoing Concern in Contemporary Japan.” Asian Anthropology 13, no. 1: 3-20. https://doi.org/10.1080/168347 8X.2014.879438. 
Danely, Jason

2014 Aging and Loss: Mourning and Maturity in Contemporary Japan. New Brunswick, N.J.: Rutgers University Press.

2016 "Affect, Infrastructure, and Vulnerability: Making and Breaking Japanese Eldercare." Medicine Anthropology Theory 3, no. 1: 198-222. https://doi. org/10.17157/mat.3.2.363.

Daniels, Inge

2010 The Japanese House: Material Culture in the Modern Home. New York: Berg.

Derrida, Jacques

1992 Given Time, 1: Counterfeit Money. Translated by Peggy Kamuf. Chicago: University of Chicago Press. Originally published in 1991.

1994 Specters of Marx: The State of the Debt, the Work of Mourning, and the New International.

Gygi, Fabio Translated by Peggy Kamuf. New York: Routledge. Originally published in 1993.

2018 “The Metamorphosis of Excess: 'Rubbish Houses' and the Imagined Trajectory of Things in Post-Bubble Japan." In Consuming Life in Post-Bubble Japan: A Transdisciplinary Perspective, edited by Katarzyna J. Cwiertka and Ewa Machotka, 129-51. Amsterdam: University of Amsterdam Press.

Han, Clara

2011 "Symptoms of Another Life: Time, Possibility, and Domestic Relations in Chile's Credit Economy." Cultural Anthropology 26, no. 1: 7-32. https://doi.org/10.1111/ j.1548-1360.2010.01078.x.

Hankins, Joseph Doyle

2013 "An Ecology of Sensibility: The Politics of Scents and Stigma in Japan." Anthropological Theory 13, nos. 1-2: 49-66. https://doi.org/10.1177/1463499613483397.

Harrison, Paul

2007 "The Space between Us: Opening Remarks on the Concept of Dwelling." Hromadžić, Azra Environment and Planning D 25, no. 4: 625-47. https://doi.org/10.1068/d365t.

2015 “'Where were they until now?' Aging, Care and Abandonment in a Bosnian Town.” Etnološka Tribina 45, no. 38: 3-29. https://doi.org/10.15378/18489540.2015.38.01.

Ingold, Tim

2000 The Perception of the Environment: Essays on Livelihood, Dwelling, and Skill. New York: Routledge.

Ivy, Marilyn

1995 Discourses of the Vanishing: Modernity, Phantasm, Japan. Chicago: University of Chicago Press.

Izuhara, Misa

2015 "Reconsidering the Housing Asset-Based Welfare Approach: Reflection from East Asian Experiences." Social Policy and Society 15, no. 2: 177-88. https://doi. Jackson, Michael D. org/10.1017/S1474746415000093.

1995 At Home in the World. Durham, N.C.: Duke University Press.

2011 Life Within Limits: Well-Being in a World of Want. Durham, N.C.: Duke University Press.

Japanese Ministry of Health, Labor, and Welfare (MHLW)

2008 "Koritsushi' zero wo mezashite [Aiming for Zero 'Isolated Deaths']." Report. https://www.mhlw.go.jp/houdou/2008/03/h0328-8.html.

2017a "Outline of the Revision of the Long-Term Care Insurance System, etc. to Strengthen the Community-Based Integrated Care System in 2017-18." Report. http://www.mhlw.go.jp/english/policy/care-welfare/care-welfare-elderly.

2017b “Population Dynamics Annual Statistics Report, 2016.” https://www.mhlw.go.jp/ toukei/saikin/hw/jinkou/kakutei16/index.html. 
Kim, Jieun

2016 "Necrosociality: Isolated Death and Unclaimed Cremains in Japan." Journal of the Royal Anthropological Institute 22, no. 2: 843-63. https://doi.org/10.1111/14679655.12491.

Langford, Jean M.

2016 "Ghostly Poetics." Paper presented at the Penn Ghost Project, University of Pennsylvania, Philadelphia, Pa., February 26.

Long, Susan Orpett

2004 "Cultural Scripts for a Good Death in Japan and the United States: Similarities and Differences." Social Science and Medicine 58, no. 5: 913-28. https://doi.

Masuda, Katsuyoshi org/10.1016/j.socscimed.2003.10.037.

2015 '“Jitaku Mitori 40man-nin jidai' he, taisei-zukuri ga kyumu [Urgent Need to Develop Plans to Face the 'Age of 400,000 Watched-Over until Death in their Own Homes'].” Nikkei Business Publications, August 10. http://techon.nikkeibp. co.jp/article/EVENT/20150810/431485.

Meyer, Morgan

2012 "Placing and Tracing Absence: A Material Culture of the Immaterial." Journal of Material Culture 17, no. 1: 103-110. https://doi.org/10.1177/1359183511433259.

Mol, Annemarie

2008 The Logic of Care: Health and the Problem of Patient Choice. New York: Routledge.

Morioka, Kiyomi

2012 "Muen shakai" ni kōreiki wo ikiru [Living to Old Age in a "Connectionless Society"]. Tokyo: Kosei Shuppansha.

National Consumer Affairs Center of Japan

2013 "Zōka suru juutaku refōm kōji no toraburu [Troubles from the Increase in Home Renovation Construction].” Report. http://www.kokusen.go.jp/news/ data/n-20130307_2.html.

Nippon Keizai Shimbun

2016 “'Tashishakai' Nippon tsuinoumika arimasu ka? 130 mannin no piriodo ['Mass-Dying Society' Japan: Could the End of Existence Be Here? 1.3 Million Period]." Lifestyle and House, February 1. http://www.nikkei.com/article/ DGXMZO96677120Z20C16A1NZBP00.

Nozawa, Shunsuke

2015 "Phatic Traces: Sociality in Contemporary Japan." Anthropological Quarterly 88, no. 2: 373-400. https://doi.org/10.1353/anq.2015.0014.

Povinelli, Elizabeth A.

2011 Economies of Abandonment: Social Belonging and Endurance in Late Liberalism. Durham, N.C.: Duke University Press.

Ricoeur, Paul

1984 Time and Narrative. Translated by Kathleen McLaughlin and David Pellauer.

Ross, Fiona C. Chicago: University of Chicago Press. Originally published in 1983.

2009 Raw Life, New Hope: Decency, Housing and Everyday Life in a Post-Apartheid Community. Claremont, South Africa: UCT Press.

Sakai, Naoki

1997 Translation and Subjectivity: On "Japan" and Cultural Nationalism. Minneapolis: University of Minnesota Press.

Sahlins, Marshall

2013 What Kinship Is — and Is Not. Chicago: University of Chicago Press.

Sand, Jordan

2003 House and Home in Modern Japan: Architecture, Domestic Space, and Bourgeois Culture, 1880-1930. Cambridge, Mass.: Harvard University Asia Center. 
Scheper-Hughes, Nancy, and Margaret M. Lock

1987 "The Mindful Body: A Prolegomenon to Future Work in Medical Anthropology." Medical Anthropology Quarterly 1, no. 1: 6-41. https://doi.org/10.1525/

Sobel, Jonathan maq.1987.1.1.02a00020.

2015 "A Sprawl of Ghost Homes in Aging Tokyo Suburbs." New York Times, August 24. http://www.nytimes.com/2015/08/24/world/a-sprawl-of-abandoned-homes-in-

Stevenson, Lisa tokyo-suburbs.html.

2014 Life Beside Itself: Imagining Care in the Canadian Arctic. Oakland: University of California Press.

Strava, Cristiana

2017 "At Home on the Margins: Care Giving and the 'Un-Homely' among Casablanca's Working Poor." City and Society 29, no. 2: 329-48. https://doi.org/10.1111/ ciso.12129.

Tamaki, Teiko

2014 "Live and Die in Solitude Away from the Family: Issues Relating to Unattended Death Kodokushi in Japan.” Hōsei riron 46, no. 4: 203-218. http://hdl.handle. net/10191/29371.

Tamiya, Nanako, Haruko Noguchi, Akihiro Nishi, Michael R Reich, Naoki Ikegami, Hideki

Hashimoto, Kenji Shibuya, Ichiro Kawachi, and John Creighton Campbell

2011 "Population Ageing and Wellbeing: Lessons from Japan's Long-Term Care Insurance Policy.” Lancet 378, no. 9797: 1183-92. https://doi.org/10.1016/S01406736(11)61176-8.

Yabe, Takeshi

2012 Hitori de shindemo kodoku ja nai: "Jiritsushi" senshinkuni America [Even If You Die Alone, You Are Not Lonely: "Independent Death" in the Developed Country America]. Tokyo: Shinchosha.

Zigon, Jarrett

2014 "An Ethics of Dwelling and a Politics of World-Building: A Critical Response to Ordinary Ethics." Journal of the Royal Anthropological Institute 20, no. 4: 746-64. https://doi.org/10.1111/1467-9655.12133. 